\title{
Evaluation of antitumor activity of tetrodotoxin extracted from liver of the Red Sea puffer fish, Lagocephalus sceleratus on liver and kidney functions of Ehrlich Solid Carcinoma bearing albino mice
}

\author{
Ahmad M. Azab, Mohamed M. Abu- Zaid,Mohamed H. Ghanem and Alaa H.H. Edris \\ Zoology Department, Faculty of Science, Al-Azhar University, Nasr City, Cairo \\ amazab2000@yahoo.comdr3laaelaraby84@yahoo.com
}

\section{ABSTRACT}

The present work aimed to evaluate the antitumor activity of tetrodotoxin (TTX) extracted from the Red Sea puffer fish, Lagocephalus sceleratus on the liver and kidney functions of Ehrlich Solid Carcinoma (EAC) bearing male albino mice. The puffer fishes were collected from the commercial catches at the Attaka fish landing station, Suez Governorate, Egypt. After 10 days of induction by Ehrlich Solid Carcinoma (EAC) cells, Ehrlich Solid Carcinoma (ESC) tumor inthigh musclesof induced mice was appeared and this time represented the zero day of the experiment. A sublethal dose of extracted TTX was administrated to mice having Ehrlich Solid Carcinoma (ESC) tumor, for a period of 3 weeks in nine equal doses (each 48 hours).

Injection of TTX to mice specimens having Ehrlich Solid Carcinoma (ESC) tumorin $\mathrm{G}_{4}$ resulted in a highly significant decrease in hepaticASAT and ALAT enzyme activities $(P<0.01)$ after the third week of the experiment, compared with that of $\mathrm{G}_{3}$. Also, the injection of TTX highly significant $(\mathrm{P}<0.05)$ improved the kidney functions (urea and creatinine) in mice specimens having Ehrlich Solid Carcinoma (ESC) tumorspecimens $\left(\mathrm{G}_{4}\right)$, comparing with that of $\mathrm{G}_{3}$ mice specimens.

Key words:Tetrodotoxin (TTX); puffer fish;Lagocephalussceleratus; Ehrlich Ascites Carcinoma (EAC); Ehrlich Solid Carcinoma (ESC); antitumor activity; liver and kidney functions

\section{INTRODUCTION}

Tetrodotoxin (TTX) is a naturally occurring toxin, it was believed to be confined to regions of South East Asia, but recent studies have demonstrated that, the toxin has spread to regions in the Pacific and the Mediterranean(1).Tetrodontiform fishes are known to accumulate tetrodotoxin (TTX) mainly in the liver and ovary through the food chain by ingesting TTX bearing organisms such as star fish, gastropods, flatworms, ribbon worms and crustaceans(2-4).

Puffer fish have been known to be toxic to humans for a long time. Tetrodotoxin (TTX) is a very potent neurotoxin that is found in a variety of marine organisms (5-11) and also in some terrestrial ones (12-15).Its toxicity is often emphasized by referring to the fact that it is over a thousand times more toxic to humans than cyanide; TTX has no known antidote (3\&16).

Tetrodotoxin had been a useful tool in identification, isolation and characterization of voltage-gated sodium channels. Tosteson (17) demonstrated that TTX has a great ability to bind to the trans-membrane glycoprotein forming the $\mathrm{Na}+$ channel which resulted in blocking it. Several research papers have been published the effect of TTX on cells of different size, type and shape. Recently, a group of Chinese scientists performed clinical trials in Canada and China using tetrodotoxin as an analgesic which reduces the intense pain caused by advanced cancer in patients. Administration of small doses of TTX resulted in pain relief lasted 2 to 3 weeks. The clinical trials indicated that the purified tetrodotoxin was safe when given in very small doses. It acts quickly and has a long duration of action. Compared to 
Ahmad M. Azab et al.

morphine, TTX was 3000 times more powerful with fewer side effects and no addictive qualities (18).

The basic aim in the use of these antitumor drugs is to inhibit the proliferation of tumor cells or kill them without damaging the normal cells. Among the most effective methods of treatment is the use of natural products which proved in many cases to have much of action less side effects than the chemical or radioactive treatments. A large number of natural products have been studied for anti-cancer activity on various experimental models $(19,20,21)$.

The use of Ehrlich solid Carcinoma (ESC) as a model in anti-cancer researches was proven by some authors to give accurate and reliable resultswhilethe reliability of such test lies in its ability to determine the value of any anticancer drug through prolongation of experimental animal life span(22-27). The reliability of such test lies in its ability to determine the value of any anticancer drug through prolongation of experimental animal lifespan in addition to the changes in number and viability of the cell line itself in addition to the volume of the liquid generated by the tumor inside the peritoneal cavity(28).

Furthermore, Wu et al. (29) suggested thatthe toxicity of different organs of the puffer fishes is variable due to the number of TTX producing bacteria present with in the fish organs. There were some researches using a sub-lethal dose of TTX in the treatment of pain due to cancer, neuropathic pain due to nerve injury because of TTX selectivity and high affinity to block the voltage-gated sodium channels of excitable membranes (30). Also TTX and similar marine neurotoxins were used in cancer therapy (31).

The present study was carried out to evaluate the antitumor activity of tetrodotoxin extracted from the liver of the Red Sea puffer fish, Lagocephalus sceleratusagainst Ehrlich Ascites Carcinoma (EAC) cells in Swiss albino mice.

\section{Tetrodotoxin (TTX) extraction}

\section{MATERIALS AND METHODS}

Five specimens of puffer fish, Lagocephalussceleratus (total length ranged between 28 and $33 \mathrm{~cm}$ ) were collected from the commercial catches at Attaka fish landing site in Suez Governorate, Egypt.Fishes were dissected and the liver was removed and kept in bags; then it was frozen at $-20^{\circ} \mathrm{C}$ till the time of extraction.

In the laboratory, the tetrodotoxin (TTX) was extracted from the liver of the puffer fish according to the method of Kawabata (32). The crude TTX were purified and concentrated by evaporating excess of methanol; then dissolved in saline solution (sodium chloride $0.9 \%$ ).

\section{Tetrodotoxin (TTX) toxicity:}

The toxicity of the extracted TTX was determined (in mouse units) according to Kawabata (32) and Noguchi \& Mahmud (33). Toxicity test were performed by a series of different concentrations which injected intra-peritoneal to different males of albino mice (20$25 \mathrm{~g}$ body weight). The survival time was recorded (by minutes), calculate the mouse unit (MU), while one mouse unit is defined as the amount of toxin required to kill a $20 \mathrm{~g}$ mouse within $30 \mathrm{~min}$ (Table 1).

\section{Cancer cell line:}

Ehrlich Ascites Carcinoma (EAC, ECACC 87032503) cells via 20-g female albino mice were used, as a model for cancer cells. The cell line was obtained from National Cancer Institute, Cairo University. The cell line of EAC-cells was maintained in the laboratory until the end of all experiments. EAC-cells were maintained by weekly intra-peritoneal transplantation of $2.5 \times 10^{6} \mathrm{EAC}$ cells/mouse into two females of albino mice specimens (18$22 \mathrm{~g}$ total weight). 


\section{Induction of Ehrlich Solid Carcinoma (ESC) tumor:}

For induction of ESC tumor, male mice specimens were injected with $0.1 \mathrm{ml}$ of EAC which diluted in saline solution in the muscle of thigh. Induction of EAC to beard mice become in thigh muscles were performed during 10 days, then a solid tumor become in small size which convenient state to begin the experiment.

\section{Experimental design:}

Eighty healthy specimens of male albino mice (22-25 g. in body weight) were used in the experiment. Mice specimens were obtained from National Researches Center in Dokki, Cairo. The animals were kept under the normal laboratory conditions. They were divided into 4 groups (each of 20 male mice). Experimental groups were separated in the cages to protect sexual desire, they exposed to 12 hours of regular light/dark periods. These animals were fed daily with vegetable, commercial protein rich pellet diet and free water supply. Experimental groups were designed as the following:

Group $1\left(\mathbf{G}_{\mathbf{1}}\right)$ : Contained 20 specimens, which injected with $0.1 \mathrm{ml}$ of saline solution only, each 48 hours for three weeks (as a control group).

Group $2\left(\mathbf{G}_{2}\right)$ : Contained 20 specimens, which injected with the liver extracted crude TTX of a dose equal $120 \mathrm{MU}$ (65 microns) dissolved in $0.1 \mathrm{ml}$ of saline solution, each 48 hours for three weeks.

Group $3\left(\mathbf{G}_{3}\right)$ : Contained 20 specimens of Ehrlich solid carcinoma (ESC) cells bearing mice, which injected with $0.1 \mathrm{ml}$ of saline solution only, each 48 hours for three weeks.

Group $4\left(\mathbf{G}_{\mathbf{4}}\right)$ : Contained 20 specimens of ESC bearing mice and treated by the injection ofliver extracted crude TTX of a dose equal $120 \mathrm{MU}$ (65 microns) dissolved in $0.1 \mathrm{ml}$ of saline solution, each 48 hours for three weeks.

\section{Blood sampling:}

At the start of the experiment (zero-day) and the end of each week (first, second and third week) of the experiment, 5 mice specimens from each group were used for blood collection from the retro-orbital venous plexus into two samples. Blood samples were taken without anticoagulant in sterile tubes for separation of serum which was used to measure the biochemical parameters.

\section{Biochemical analysis:}

Activities of serum aspartate transaminase and alanine transaminase (ASAT and ALAT IU/ml) were determined according to Schumann \&Klauke (34) by using instruction manual of Human reagent kits purchased from Human Gesell Schaft for Biochemical and Diagnostic mph, Germany. Creatinine and urea levels in serum $(\mathrm{mg} / \mathrm{dl})$ were determined according to Young (35) by using the diagnostic of Diamond kits Diagnostic; MDCS GmbH Schiffgraben 4130175 Hannover, Germany.

\section{Statistical analysis:}

The data obtained from this investigation were statistically analyzed using one way ANOVA (T-test). Means of the same column followed by different small letters were significantly different between different groups in the same period. Means of the same rawfollowed by different capital letters were significantly different between different periods for the same group. 
Table (1): Mouse units (MU) determination table (according to Kawabata, 32)

\begin{tabular}{|c|c|c|c|c|c|}
\hline Time(min.) & $\begin{array}{c}\text { Mouse } \\
\text { units }\end{array}$ & Time(min.) & $\begin{array}{c}\text { Mouse } \\
\text { units }\end{array}$ & Time(min.) & $\begin{array}{c}\begin{array}{c}\text { Mouse } \\
\text { units }\end{array} \\
\end{array}$ \\
\hline 4.00 & 5.62 & 6.40 & 2.53 & 13.00 & 1.42 \\
\hline 4.05 & 5.40 & 6.50 & 2.46 & 13.15 & 1.40 \\
\hline 4.10 & 5.19 & 7.00 & 2.39 & 13.30 & 1.38 \\
\hline 4.15 & 5.00 & 7.10 & 2.33 & 13.45 & 1.36 \\
\hline 4.20 & 4.82 & 7.20 & 2.27 & 14.00 & 1.34 \\
\hline 4.25 & 4.66 & 7.30 & 2.22 & 14.30 & 1.32 \\
\hline 4.30 & 4.50 & 7.40 & 2.17 & 15.00 & 1.30 \\
\hline 4.35 & 4.36 & 7.50 & 2.12 & 15.30 & 1.28 \\
\hline 4.40 & 4.23 & 8.00 & 2.08 & 16.00 & 1.26 \\
\hline 4.45 & 4.10 & 8.15 & 2.01 & 16.30 & 1.24 \\
\hline 4.50 & 3.99 & 8.30 & 1.96 & 17.00 & 1.23 \\
\hline 4.55 & 3.88 & 8.45 & 1.91 & 17.30 & 1.21 \\
\hline 5.00 & 3.72 & 9.00 & 1.86 & 18.00 & 1.19 \\
\hline 5.05 & 3.68 & 9.15 & 1.81 & 18.30 & 1.18 \\
\hline 5.10 & 3.58 & 9.30 & 1.77 & 19.00 & 1,17 \\
\hline 5.15 & 3.50 & 9.45 & 1.74 & 19.30 & 1.15 \\
\hline 5.20 & 3.42 & 10.00 & 1,70 & 20.00 & 1.14 \\
\hline 5.25 & 3.31 & 10.15 & 1,67 & 20.30 & 1.13 \\
\hline 5.30 & 3.26 & 10.30 & 1,64 & 21.00 & 1.12 \\
\hline 5.35 & 3.19 & 10.45 & 1.61 & 21.30 & 1.11 \\
\hline 5.40 & 3.13 & 11.00 & 1.58 & 22.00 & 1.10 \\
\hline 5.45 & 3.07 & 11.15 & 1.56 & 22.30 & 1.09 \\
\hline 5.50 & 3.01 & 11.30 & 1.53 & 23.00 & 1.08 \\
\hline 5.55 & 2.95 & 11.45 & 1.51 & 23.30 & 1.08 \\
\hline 6.00 & 2.88 & 12.00 & 1.49 & 24.00 & 1.07 \\
\hline 6.10 & 2.79 & 12.15 & 1.47 & 24.30 & 1.06 \\
\hline 6.20 & 2.70 & 12.30 & 1.45 & 25.00 & 1.05 \\
\hline 6.30 & 2.61 & 12.45 & 1.43 & & \\
\hline
\end{tabular}

\section{RESULTS}

1. Tetrodotoxin (TTX) toxicity:

Results of tetrodotoxin (TTX) toxicity showed that the TTX extracted from the liver of the Red Sea puffer fish, Lagocephalus sceleratus was moderately toxic. The mouse unit amounted $1.300 \mathrm{mg}$ of crude liver TTX. Thus, the sub-lethal dose of TTX was equal to $65 \mu$ (1/20 of mouse unit).

\section{Aspartate aminotransferases (ASAT) Activity (IU/L):}

The results of Table (2) showed that the activity of ASATin the blood serum of the control albino mice which injected with saline $\left(\mathrm{G}_{1}\right)$ ranged from 42 to 54 IU/Lwith an average of $47.8 \pm 4.49 \mathrm{IU} / \mathrm{L}$ at zero-day.This ASAT average was non-significantly varied (P>0.05) during the next 3 weeks of the experiment. However, the ASATactivityin TTX injected group $\left(\mathrm{G}_{2}\right)$ greatly increased from $47.8 \pm 4.494 \mathrm{mg} / \mathrm{ml}$ during the zero-day to the 
maximum average of $770 \pm 634.2 \mathrm{IU} / \mathrm{L}(\mathrm{P}<0.01)$ after the first week of the experiment (Fig. $1)$.

In the case of mice specimens having Ehrlich Solid Carcinoma tumor $\left(\mathbf{G}_{\mathbf{3}}\right)$, theactivityof ASATwas very high during all periods of experiment, ranging between $683 \pm$ 114IU/Lin zero-dayand $1373 \pm 60.14 \mathrm{IU} / \mathrm{L}$ afterthe third week. The variation of ASAT was highly significant $(P<0.01)$ between $\mathrm{G}_{3}$ and that of $\mathrm{G}_{1}$. On the other hand, injection of TTX to mice specimens having Ehrlich Solid Carcinoma tumorin $\mathbf{G}_{\mathbf{4}}$ greatly decreased the activity of ASAT to $870.4 \pm 74.01 \mathrm{IU} / \mathrm{L}$ ( $\mathrm{P}<0.01)$ after the third week, compared with that of $\mathrm{G}_{3}$ (Table 2 and Fig. 1).

\section{Alanine aminotransferase (ALAT) activity (IU/L):}

The results of Table (3) and Figure (2)showed that the activity of ALATin the blood serum of the control albino mice which injected with saline $\left(\mathrm{G}_{1}\right)$ ranged from 34 to $50 \mathrm{IU} / \mathrm{L}$ with an average of $42.8 \pm 6.419 \mathrm{IU} / \mathrm{L}$ at zero-day.This ALAT average was nearly similar (P>0.05) during the next 3 weeks of the experiment. This ALATactivityin TTX injected group $\left(\mathrm{G}_{2}\right)$ greatly increased $(\mathrm{P}<0.01)$ and reached to maximum average of $181.4 \pm$ 97.46IU/L after the second week of the experiment and it sharply decreased $(\mathrm{P}<0.01)$ after the third week of experiment to $114 \pm 28.38 \mathrm{IU} / \mathrm{L}$.

In the case of $\mathrm{G}_{3}$, having Ehrlich Solid Carcinoma tumor, theactivityof ALATwas highly significantly varied $(\mathrm{P}<0.01)$ during all periods of experiment, starting with an average of $141.3 \pm 25.79 \mathrm{IU} / \mathrm{L}$ in zero-dayreaching to an average of $236 \pm 64.14 \mathrm{IU} / \mathrm{L}$ afterthe second week. On the other hand, injection of TTX to mice specimens having Ehrlich Solid Carcinoma tumor in $\mathrm{G}_{4}$ gradually decreased the activity of ALAT to $109 \pm 13.66 \mathrm{IU} / \mathrm{L}$ $(\mathrm{P}<0.01)$ after the third week, compared with that of $\mathrm{G}_{3}$ (Table 2 and Fig. 2).

\subsection{Concentration of serum urea (mg/dl):}

The results showed that the concentration of ureain the blood serum of the control albino mice which injected with saline $\left(\mathrm{G}_{1}\right)$ ranged from 16 to $29 \mathrm{mg} / \mathrm{dl}$ with an average of $23.0 \pm 4.85 \mathrm{mg} / \mathrm{dlat}$ zero-day. This average of serum urea was nearly similar $(\mathrm{P}>0.05)$ during the next 3 weeks of the experiment. However, the serum urea in TTX injected group $\left(\mathrm{G}_{2}\right)$ increased from $23.0 \pm 4.848 \mathrm{mg} / \mathrm{dl}$ during the zero-day to the maximum average of $33.6 \pm$ $5.41 \mathrm{mg} / \mathrm{dl}(\mathrm{P}<0.05)$ after the first week of the experiment, then gradually decreased during the next period, reaching the minimum average $(19.8 \pm 1.3)$ after the third week (Table 4and Fig. $3)$.

In the case of mice specimens having Ehrlich Solid Carcinoma (ESC) tumor( $\left.\mathbf{G}_{3}\right)$, theserum urea concentrationwas highly significant varied $(\mathrm{P}<0.01)$ than that of the control group, during all periods of experiment, ranging between $33.33 \pm 0.41 \mathrm{mg} / \mathrm{dlin}$ zero-dayand $44.8 \pm 2.88 \mathrm{mg} / \mathrm{dl}$ afterthe third week. While, the injection of TTX to mice specimens having Ehrlich Solid Carcinoma (ESC) tumor in $\mathrm{G}_{4}$ gradually decreased the serum urea from $33.33 \pm$ $0.41 \mathrm{mg} / \mathrm{d}$ lin zero-day to $27.6 \pm 2.7 \mathrm{mg} / \mathrm{mlafter}$ the third week. The variation of urea in $\mathrm{G}_{4}$ specimens was highly significant $(\mathrm{P}<0.01)$, comparing with that of $\mathrm{G}_{3}$ specimens (Table 4 and Fig. 3).

\section{Concentration of creatinine $(\mathrm{mg} / \mathrm{dl})$ :}

The results of Table (5) and Figure (4) showed that the creatinine concentration in the blood serum of the control albino mice which injected with saline $\left(\mathrm{G}_{1}\right)$ ranged from 0.58 to $1.1 \mathrm{mg} / \mathrm{dl}$ with an average of $0.81 \pm 0.19 \mathrm{mg} / \mathrm{dlat}$ zero-day. This serum creatinine average was nearly similar $(\mathrm{P}>0.05)$ during the next 3 weeks of the experiment, reaching the maximum 
average of $0.85 \pm 0.18 \mathrm{mg} / \mathrm{dl}$. However, the serum creatinine in TTX injected group $\left(\mathrm{G}_{2}\right)$ increased to an average of $0.90 \pm 0.41 \mathrm{mg} / \mathrm{dl}$ after the second week of the experiment then decreased to the minimum average of $0.57 \pm 0.31 \mathrm{mg} / \mathrm{dl}(\mathrm{P}<0.01)$ after the third week of experiment.

In the case of $\mathrm{G}_{3}$, having Ehrlich Solid Carcinoma tumor, the concentration of serum creatinine was highly significant varied $(\mathrm{P}<0.01)$ than that of control group during all periods of experiment, reaching the maximum average of $1.46 \pm 0.11 \mathrm{mg} / \mathrm{dl}$ afterthe third week. On the other hand, injection of TTX to mice specimens having Ehrlich Solid Carcinoma tumor $\left(\mathbf{G}_{4}\right)$ highly significant decreased this average of creatinine concentration from $1.37+$ $0.11 \mathrm{mg} / \mathrm{dl}$ at zero-day to the $0.78 \pm 0.152 \mathrm{mg} / \mathrm{dlafter}$ the third week (Table, 5and Fig. 4).

The results of Table (6) indicated that there are highly significant differences $(\mathrm{P}<0.01)$ between different experimental groupsin ASAT and ALAT enzyme activities, as well as urea and creatinine concentrations. While, non-significant differences were noticed between the different periods of the experiment in these parameters.

Table (2): Effect of tetrodotoxin extracted from the liver of the Red Sea puffer fish, $L$. sceleratusonaspartate aminotransferase "ASAT" activity (IU/L) in blood serum of albino mice groups during the different experimental periods.

\begin{tabular}{|c|c|c|c|c|c|}
\hline \multicolumn{2}{|c|}{$\begin{array}{ll}\text { Groups } & \text { Periods } \\
\end{array}$} & Zero-day & $1^{\text {st }}$ week & $2^{\text {nd }}$ week & $3^{\text {rd }}$ week \\
\hline \multirow{3}{*}{$\mathbf{G}_{1}$} & Range & $42-54$ & $40-56$ & $38-59$ & $36-58$ \\
\hline & Average \pm SD & $47.8 \pm 4.49$ & $47.4 \pm 6.47$ & $48.2 \pm 9.42$ & $47.6 \pm 9.24$ \\
\hline & Significance & A a & A a & A a & $\mathbf{A} \mathbf{a}$ \\
\hline \multirow{3}{*}{$\mathbf{G}_{2}$} & Range & $42-54$ & $140-1560$ & $356-530$ & $463-682$ \\
\hline & Average \pm SD & $47.8 \pm 4.49$ & $770.6 \pm 634.2$ & $464 \pm 65.86$ & $567.6 \pm 77.61$ \\
\hline & Significance & $\mathbf{A} \mathbf{a}$ & B b & B b & $\mathbf{C b}$ \\
\hline \multirow{3}{*}{$\mathbf{G}_{3}$} & Range & $500-800$ & $995-1050$ & $1031-1290$ & $1300-1465$ \\
\hline & Average \pm SD & $683 \pm 114$ & $1015 \pm 21.51$ & $1158 \pm 113.71$ & $1373.2 \pm 60.14$ \\
\hline & Significance & $\mathbf{A ~ b}$ & B b & $\mathrm{C} \mathrm{c}$ & D c \\
\hline \multirow{3}{*}{$\mathbf{G}_{4}$} & Range & $500-800$ & $670-770$ & $870-988$ & $773-975$ \\
\hline & Average \pm SD & $683 \pm 114$ & $722 \pm 35.63$ & $931.8 \pm 56.41$ & $870.4 \pm 74.01$ \\
\hline & Significance & $\mathbf{A ~ b}$ & A c & B d & B d \\
\hline
\end{tabular}

The different capital letters in the same raw are statistically significant and the different small letters in the same column are statistically significant. 
Evaluation of antitumor activity of tetrodotoxin extracted from liver of the Red Sea puffer fish, Lagocephalus sceleratus on liver and kidney functions of Ehrlich Solid Carcinoma bearing albino mice

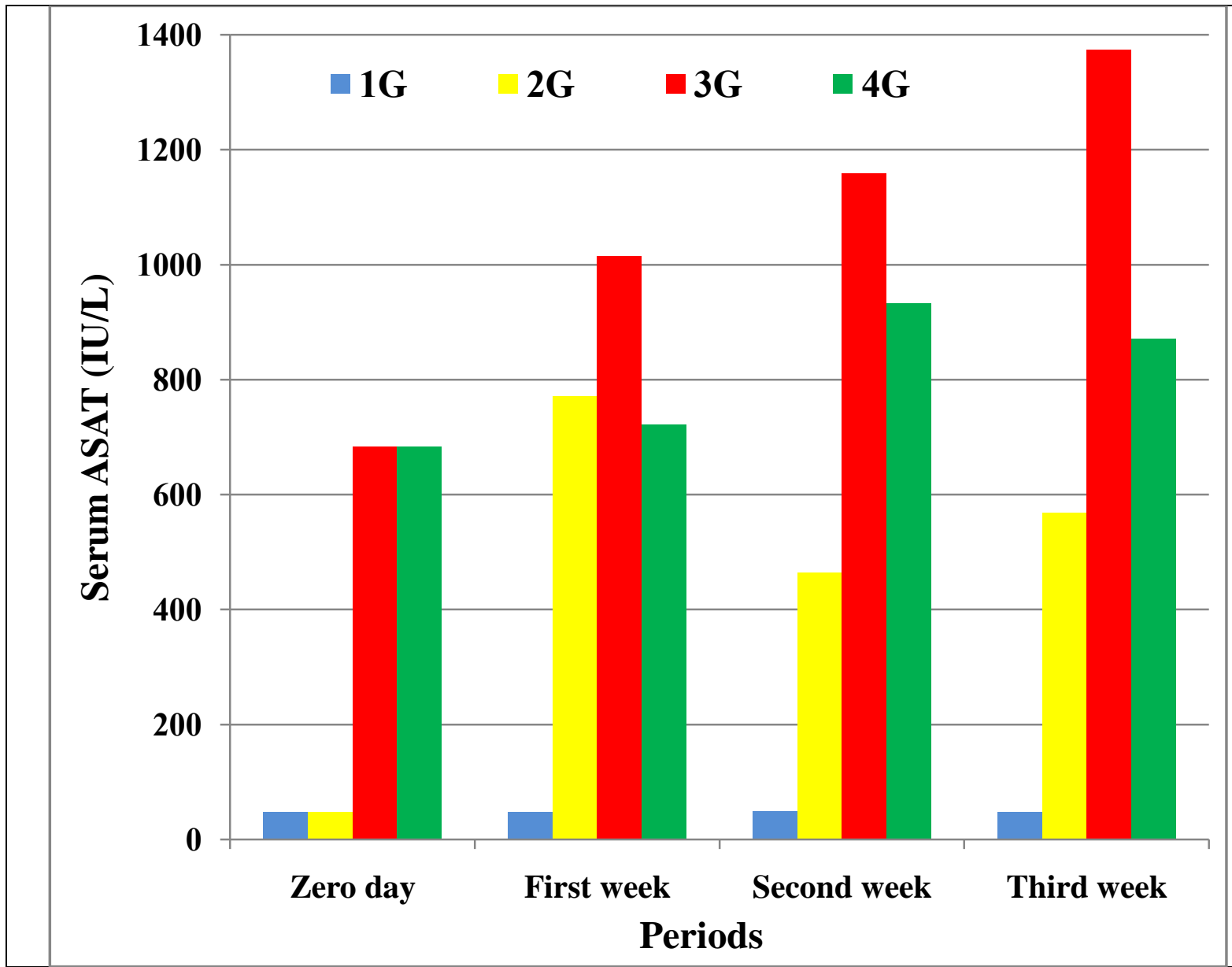

Fig. (1): Aspartate aminotransferases (ASAT) activity (IU/L) in the blood serum of albino micegroups during the different experimental periods.

Table (3): Effect of tetrodotoxin extracted from the liver of the Red Sea puffer fish, $L$. sceleratusonalanine aminotransferase "ALAT" activity (IU/L) in blood serum of albino mice groups during the different experimental periods.

\begin{tabular}{|c|l|c|c|c|c|}
\hline \multirow{2}{*}{ Groups } & Periods & Zero-day & $\mathbf{1}^{\text {st }}$ week & $\mathbf{2}^{\text {nd }}$ week & $\mathbf{3}^{\text {rd }}$ week \\
\hline \multirow{3}{*}{$\mathbf{G}_{\mathbf{1}}$} & Range & $34-50$ & $35-55$ & $36-46$ & $35-55$ \\
\cline { 2 - 6 } & Average \pm SD & $42.8 \pm 6.419$ & $42.2 \pm 7.85$ & $43.2 \pm 5.16$ & $44.6 \pm 8.87$ \\
\cline { 2 - 6 } & Significance & $\mathbf{A ~ a}$ & $\mathbf{A a}$ & $\mathbf{A a}$ & $\mathbf{A a}$ \\
\hline \multirow{3}{*}{$\mathbf{G}_{\mathbf{2}}$} & Range & $34-50$ & $125-225$ & $78-296$ & $72-152$ \\
\cline { 2 - 7 } & Average \pm SD & $42.8 \pm 6.42$ & $173.6 \pm 40.37$ & $181.4 \pm 97.46$ & $114 \pm 28.38$ \\
\cline { 2 - 7 } & Significance & $\mathbf{A a}$ & $\mathbf{B b}$ & $\mathbf{B b}$ & $\mathbf{C ~ b}$ \\
\hline \multirow{3}{*}{$\mathbf{G}_{\mathbf{3}}$} & Range & $100-169$ & $120-265$ & $128-285$ & $145-153$ \\
\cline { 2 - 7 } & Average \pm SD & $141.3 \pm 25.79$ & $191.2 \pm 51.28$ & $236 \pm 64.14$ & $147.6 \pm 3.29$ \\
\cline { 2 - 7 } & Significance & $\mathbf{A ~ b}$ & $\mathbf{A ~ b}$ & $\mathbf{B b}$ & $\mathbf{C c}$ \\
\hline \multirow{3}{*}{$\mathbf{G}_{\mathbf{4}}$} & Range & $100-169$ & $120-135$ & $82-130$ & $87-124$ \\
\cline { 2 - 7 } & Average \pm SD & $141.3 \pm 25.79$ & $126.6 \pm 5.41$ & $114.2 \pm 19.14$ & $109 \pm 13.66$ \\
\cline { 2 - 7 } & Significance & $\mathbf{A ~ b}$ & $\mathbf{A ~ c}$ & $\mathbf{B ~ c}$ & $\mathbf{B ~ d}$ \\
\hline
\end{tabular}

The different capital letters in the same raw are statistically significant and the different small letters in the same column are statistically significant. 
Ahmad M. Azab et al.

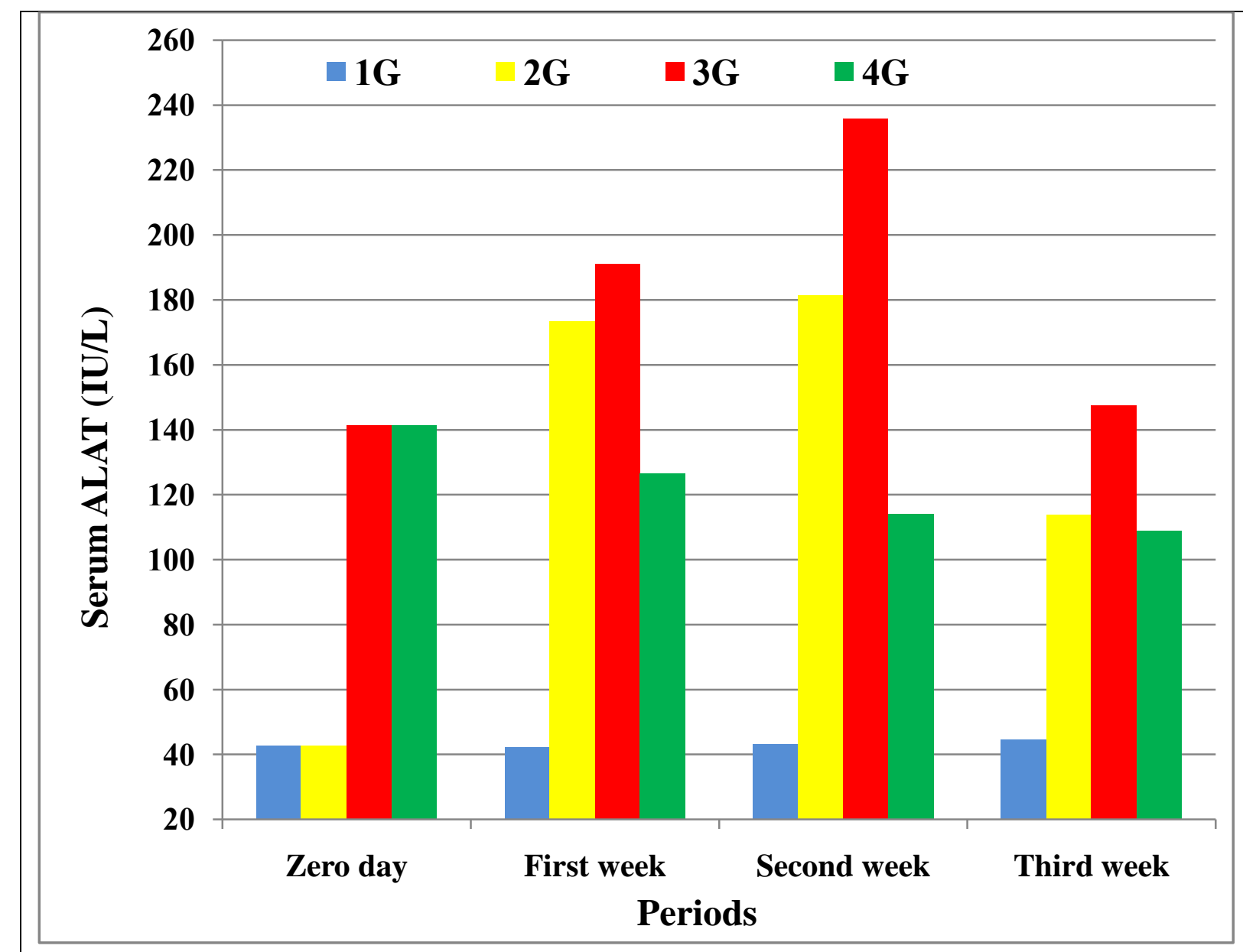

Fig. (2): Alanine aminotransferases (ALAT) activity (IU/L) in the blood serum of albino micegroups during the different experimental periods.

Table (4): Effect of tetrodotoxin extracted from the liver of the Red Sea puffer fish, $L$. sceleratusonurea concentration $(\mathrm{mg} / \mathrm{dl})$ in blood serum of albino mice groups during the different experimental periods.

\begin{tabular}{|c|c|c|c|c|c|}
\hline \multicolumn{2}{|c|}{$\begin{array}{ll}\text { Groups } & \text { Periods } \\
\end{array}$} & Zero-day & $1^{\text {st }}$ week & $2^{\text {nd }}$ week & $3^{\text {rd }}$ week \\
\hline \multirow{3}{*}{$\mathbf{G}_{1}$} & Range & $16-29$ & $19-27$ & $17-26$ & $15-28$ \\
\hline & Average \pm SD & $23 \pm 4.848$ & $21.8 \pm 3.56$ & $22.2 \pm 3.42$ & $20.6 \pm 4.88$ \\
\hline & Significance & A a & Aa & Aa & Aa \\
\hline \multirow{3}{*}{$\mathbf{G}_{2}$} & Range & $16-29$ & $23-30$ & $27-40$ & $18-21$ \\
\hline & Average \pm SD & $23 \pm 4.848$ & $33.6 \pm 5.41$ & $26 \pm 2.55$ & $19.8 \pm 1.30$ \\
\hline & Significance & $\mathbf{A} \mathbf{a}$ & $\mathbf{A} \mathbf{b}$ & $\mathbf{B b}$ & $\mathbf{C} \mathbf{a}$ \\
\hline \multirow{3}{*}{$\mathbf{G}_{\mathbf{3}}$} & Range & $33-34$ & $42-48$ & $29-41$ & $41-49$ \\
\hline & Average \pm SD & $33.33 \pm 0.41$ & $44.8 \pm 2.16$ & $35.4 \pm 5.03$ & $44.6 \pm 2.88$ \\
\hline & Significance & $\mathbf{A ~ b}$ & B c & $\mathbf{A} \mathbf{b}$ & $\mathbf{B b}$ \\
\hline \multirow{3}{*}{$\mathbf{G}_{4}$} & Range & $33-34$ & $27-344$ & $20-34$ & $25-32$ \\
\hline & Average \pm SD & $33.33 \pm 0.41$ & $30.8 \pm 3.11$ & $28.8 \pm 5.81$ & $27.6 \pm 2.70$ \\
\hline & Significance & A b & B d & A c & A c \\
\hline
\end{tabular}

The different capital letters in the same raw are statistically significant and the different small letters in the same column are statistically significant. 
Evaluation of antitumor activity of tetrodotoxin extracted from liver of the Red Sea puffer fish, Lagocephalus sceleratus on liver and kidney functions of Ehrlich Solid Carcinoma bearing albino mice

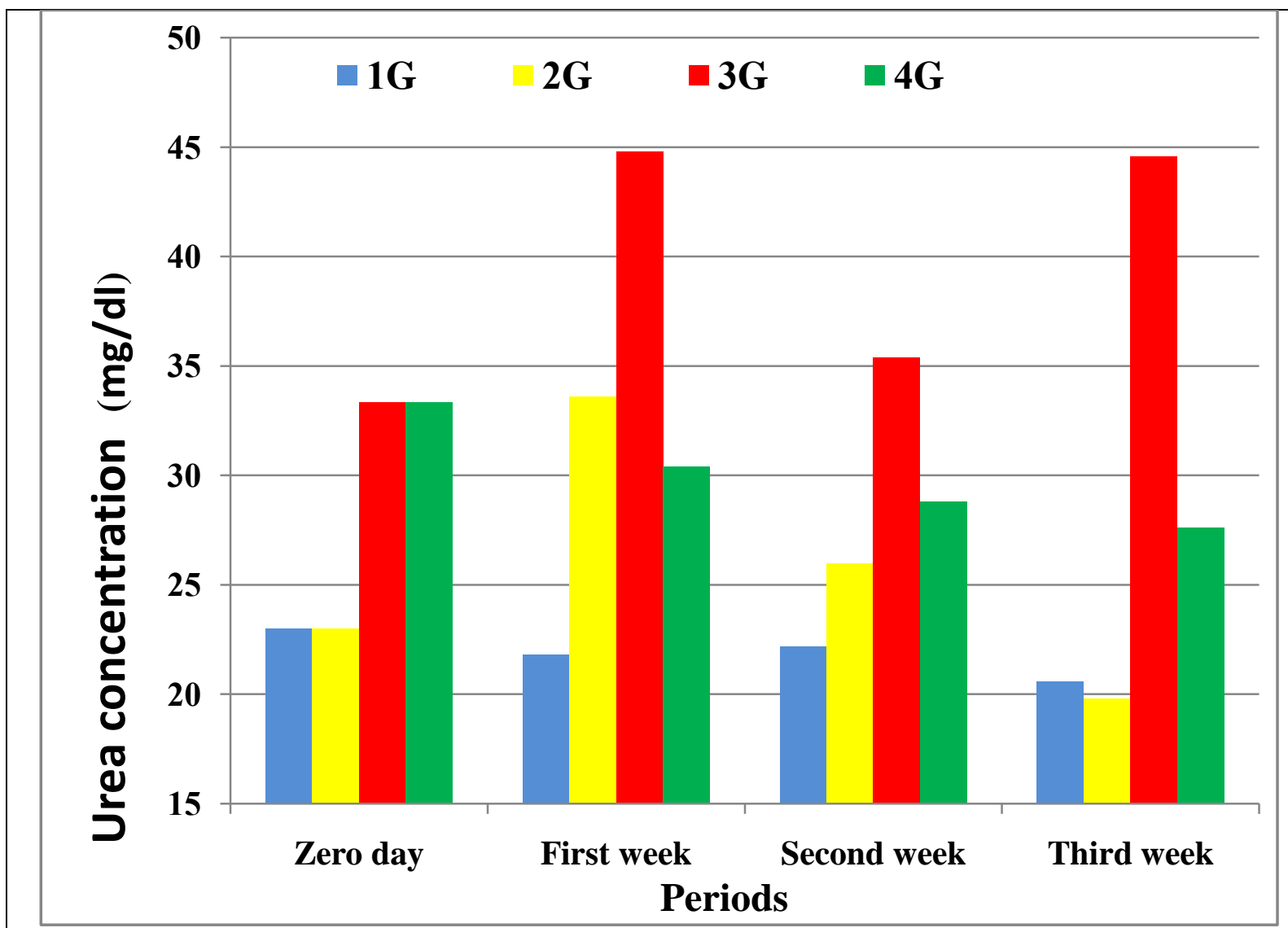

Fig. (3): Concentration of urea(mg/dl)in the blood serum of albino mice groups during the different experimental periods.

Table (5): Effect of tetrodotoxin extracted from the liver of the Red Sea puffer fish, $L$. sceleratusoncreatinine concentration $(\mathrm{mg} / \mathrm{dl})$ in blood serum of albino mice groups during the different experimental periods.

\begin{tabular}{|c|c|c|c|c|c|}
\hline \multicolumn{2}{|c|}{$\begin{array}{ll}\text { Groups } & \text { Periods } \\
\end{array}$} & Zero-day & $1^{\text {st }}$ week & $2^{\text {nd }}$ week & $3^{\text {rd }}$ week \\
\hline \multirow{3}{*}{$\mathbf{G}_{1}$} & Range & $0.58-1.1$ & $0.69-0.99$ & $0.66-1.09$ & $0.65-1.12$ \\
\hline & Average \pm SD & $0.81 \pm 0.195$ & $0.83 \pm 0.14$ & $0.82 \pm 0.19$ & $0.85 \pm 0.18$ \\
\hline & Significance & A a & A a & A a & Aa \\
\hline \multirow{3}{*}{$\mathbf{G}_{2}$} & Range & $0.58-1.1$ & $0.52-0.82$ & $0.42-1.4$ & $0.32-0.37$ \\
\hline & Average \pm SD & $0.81 \pm 0.195$ & $0.66 \pm 0.13$ & $0.90 \pm 0.41$ & $0.57 \pm 0.231$ \\
\hline & Significance & $\mathbf{A} \mathbf{a}$ & $\mathbf{B} \mathbf{b}$ & $\mathbf{A} \mathbf{a}$ & $\mathbf{B b}$ \\
\hline \multirow{3}{*}{$\mathbf{G}_{3}$} & Range & $1.2-1.5$ & $1.0-1.4$ & $0.95-1.2$ & $1.3-1.61$ \\
\hline & Average \pm SD & $1.37 \pm 0.11$ & $1.2 \pm 0.14$ & $1.07 \pm 0.097$ & $1.46 \pm 0.11$ \\
\hline & Significance & $\mathbf{A ~ b}$ & B c & $\mathbf{B} \mathbf{b}$ & A c \\
\hline \multirow{3}{*}{$\mathbf{G}_{\mathbf{4}}$} & Range & $1.2-1.5$ & $0.62-0.01$ & $0.7-0.86$ & $0.61-0.1$ \\
\hline & Average \pm SD & $1.37 \pm 0.11$ & $0.802 \pm 0.14$ & $0.81 \pm 0.063$ & $0.78 \pm 0.152$ \\
\hline & Significance & $\mathbf{A ~ b}$ & $\mathbf{B} \mathbf{a}$ & $\mathbf{B} \mathbf{a}$ & $\mathbf{B} \mathbf{a}$ \\
\hline
\end{tabular}

The different capital letters in the same raw are statistically significant and the different small letters in the same column are statistically significant. 
Ahmad M. Azab et al.

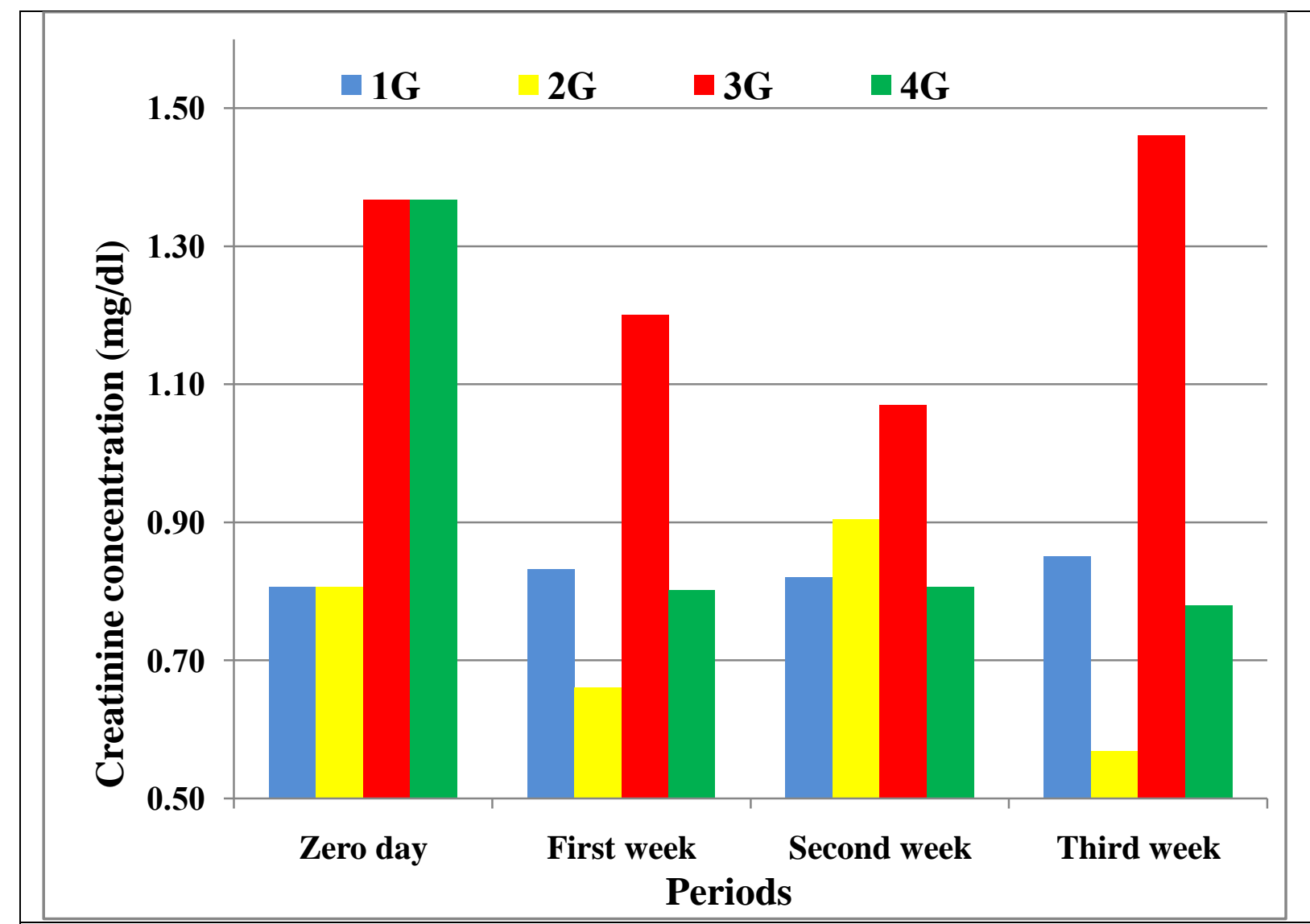

Fig. (4): Concentration of creatinine(mg/dl)in the blood serum of albino mice groups during the different experimental periods.

Table (6): Analysis of variance (ANOVA) based on biochemical parameters in the blood of albino mice groups during the different periods.

\begin{tabular}{|c|c|c|c|c|}
\hline Parameters & Source of Variation & df & F & P-value \\
\hline \multirow{5}{*}{ ASAT } & Groups & 3 & $24.253^{* * *}$ & 0.0001 \\
\cline { 2 - 5 } & $\begin{array}{c}\text { Experimental periods } \\
\text { (weeks) }\end{array}$ & 3 & $3.0422 \mathrm{NS}$ & 0.0851 \\
\cline { 2 - 5 } & Error & 9 & - & - \\
\cline { 2 - 5 } & Total & 15 & - & - \\
\hline \multirow{5}{*}{ ALAT } & Groups & 3 & $9.6610 * *$ & 0.0035 \\
\cline { 2 - 5 } & Experimental periods & 3 & $1.8127 \mathrm{NS}$ & 0.2149 \\
\cline { 2 - 5 } & Error & 9 & - & - \\
\hline \multirow{5}{*}{ Urea } & Total & 15 & - & - \\
\cline { 2 - 5 } & Groups & 3 & $9.3094 * *$ & 0.0040 \\
\cline { 2 - 5 } & Experimental periods & 3 & $0.1461 \mathrm{NS}$ & 0.9296 \\
\cline { 2 - 5 } & Error & 9 & - & - \\
\hline \multirow{5}{*}{ Creatinine } & Total & 3 & $6.8660^{*}$ & 0.0105 \\
\cline { 2 - 5 } & Groups & 3 & $1.3256 \mathrm{NS}$ & 0.3256 \\
\cline { 2 - 5 } & Experimental periods & 9 & - & - \\
\cline { 2 - 5 } & Groups & 15 & - & - \\
\hline
\end{tabular}

Note: $*=$ significant $; * * * * *=$ highly significant and N.S= non-significant. 


\section{DISCUSSION}

In the present study, local treatment with TTX resulted in a significant decrease in the activity of ASAT \& ALAT values after the third week. These data in compared with that of untreated ESC mice group (G3) which recorded the most increasing values through all periods of the study. TTX has brought back values of ASAT and ALAT in ESC group (G4) to nearly normal mice group; indicating the reduction of tumor activity.

Also, the present results were supported by Roselli et al.(36) and Abd El-Motelp \& Zaazaa(37), who revealed that, TTX induced a down-regulation of enzyme synthesis. They showed that, treatment with TTX markedly decreased hepato-aminotransferase activity.

Abd El-Dayem et al. (38) discussed effects of tetrodotoxin and/or doxorubicin on Ehrlich ascites showed significant increase in the liver activity enzymes of tumor-bearing mice when compared with the normal control mice.

Similar results have been obtained from treatment with other natural products such as green tea (39); Indigofera plant extract (40); Nigella sativa seeds (41); rosemary (42)and grape seeds extract (GSE) (43) on Ehrlich ascites tumor (EAT) cells.

The present study recorded an increase of values in the concentration of urea and creatinine in mice specimens having Ehrlich solid carcinoma tumor. These results are indications to kidney biochemical markers of solid tumor bearing mice. The treatment with TTX had a significant decrease in these values, referring to the efficiency of crude TTX extracted from puffer fish. Also, these results brought back of kidney biochemical markers nearly to the normal control group.

All of the changes in treated group were side effects as a weakly hepato-renal toxicity of TTX. These changes indicated that TTX doses were accumulated in mice organs. No significant changes were observed for either urea or creatinine levels, suggesting no renal toxicity as well as for liver enzymes during the first and second weeks of the experiment. But, significant decreases in urea, creatinine and transaminase activities were recorded in the treated group (G4) with TTX in relation to ESC control.

These results were supported by Subramanian \& Gowry(44). They found a significant antitumor activity of Brassica oleraceaitalica on EAC bearing mice. In short-run, no toxicity observed in hepato-renal system. But, at the long-run, an increase was recorded in the urea and transaminase activity (ASAT \& ALAT) indicating its hepato-renal dysfunction and metabolism disorder.

The present observations declared that, activity of liver and kidney markers showed a significant anti-metastatic effect of TTX on ESC bearing mice. Treatment with TTX brought back the activity of hepatic parameters and the concentration of kidney parameters to adverse effect of aggressive carcinoma cells. Also, anti-metastatic mechanism has occurred by transformed carcinoma cells which multiplicated, migrated and invaded liver and Kidney through blood and lymphatic systems.

These results agree with the findings of Fouda(31) on cancer metastasis in liver,where plasma membrane-bound liver enzyme strongly affected by liver cellular damage, they had a potent inhibitor of the neoplastic process as a result of its pivotal role in the cellular antioxidant system.

Jayaram et al.(45) stated that the best method of cancer treatment is the one causes cancer cells to kill themselves (i.e. to undergo apoptosis-programmed cell death) instead of overall necrosis. Such an approach will reduce the adverse side-effects of chemotherapy.

Also, Salem et al.(46) observed that Levamisole can be used as anti-cancer agent when combined with chlorambucil. It has improved to liver and kidney functions by increases apoptosis rate of EAC leading to an increase in survival rate of cancer bearing mice. They 
found a significant increase of ALAT, ASAT and creatinine in group of Ehrlich ascites carcinoma bearing mice. But, it has adverse effect on the liver and kidneys functions.

Otherwise, grape seeds extraction (GSE) which used as treatment for cancer cell invasion, it showed amelioration to urea and creatinine values toward normal in comparing to EAC group, which had increase in creatinine and blood urea nitrogen levels that may be attributed to renal tissue damage (43).

\section{REFFERENCES}

1- Bane, V.; Lehane, M.; Dikshit, M.; O’Riordan A. and Furey, A. (2014): Tetrodotoxin chemistry, toxicity, source, distribution and detection toxins, 6: 693-755.

2- Noguchi, T.; Arakawa, O. and Takatani, T. (2006): TTX accumulation in puffer fish. Comparative biochemistry and physiology Part D: J. of Genomics and Proteomics, 1 (1): 145-152.

3- Iked, k.; Mara, B.A. V.; Hond, S.; Ohtsuk, S.; Arakaw, S.; Takatan,T.; Asakaw, M. and Boxshal,G. (2006): Accumulation of tetrodotoxin (TTX) in Pseudocaligus fugu, a parasitic copepod from panther puffer Takifugu pardalis, but without vertical transmission, using an immune-enzymatic technique. J. of Toxicon.,48 (2006) 116-122.

4- Wajant, H. (2009): The role of TNF in cancer. Results and Problems in Cell Differentiation 49: 1-15.

5- Asakawa, M., Toyoshima, T., Shida, Y., Noguchi, T., Miyazawa, K.(2000): Paralytic toxins in a ribbon worm Cephalothrix species (Nemertean) adherent to cultured oysters in HiroshimaBay, Hiroshima Prefecture, Japan. J. of Toxicon, 38: 763-773.

6- Mahmud, Y.; Okada, K.; Takatani, T.; Kawatsu, K.; Hamano, Y.; Arakawa, O. and Noguchi, T. (2003): Intra-tissue distribution of tetrodotoxin in two marine puffers Takifugu vermicularis and Chelonodon patoca. Toxicon, 41: 13-18.

7- Jang, J. and Yotsu-Yamashita, M. (2006): Distribution of tetrodotoxin, saxitoxin, and their analogs among tissues of the puffer fish Fugupardalis. Toxicon, 48: 980-987.

8- Jang, J.-H.; Lee, J. S. andYotsu-Yamashita, M. (2010): LC/MS analysis of tetrodotoxin and its deoxy analogs in the marine puffer fish Fugu niphobles from the southern coast of Korea, and in the brackish water puffer fishes Tetraodon nigroviridis and Tetraodon biocellatus from Southeast Asia. Mar. Drugs., 8: 1049-1058.

9- Chulanetra, M.; Sookrung, N.; Srimanote, P.; Indrawattana, N.; Thanongsaksrikul, J.; Sakolvaree, Y.; Nguan, M.C.; Kurazono H and Chaicumpa, W. (2011): Toxic marine puffer fish in Thailand seas and tetrodotoxin. J. Toxins, 3 (10): 1249-1262.

10-Luo, X.; Yu, R.C.; Wang, X.J. and Zhou, M.J. (2012): Toxin composition and toxicity dynamics of marine gastropod Nassarius spp. collected from Lianyungang, China. Food Addit. Contam. A, (29): 117-127.

11- Yasumoto, T.; Yotsu, M.; Murata, M.and Naoki, H. (1988): New tetrodotoxin analogues from the newt Cynopsensicauda. J.Am.Chem. Soc., 110:2344-2345.

12- Yotsu-Yamashita, M. and Mebs, D. (2001): The levels of tetrodotoxin and its analogue 6- epitetrodotoxin in the red-spotted newt, Notophthalmus viridescens. Toxicon, 39(8): 1261-1263.

13- Pires, O.R., Jr.; Sebben, A.; Schwartz, E.F.; Bloch, C., Jr.; Morales, R.A.V. and Schwartz, C.A. (2003): The occurrence of 11-oxotetrodotoxin, a rare tetrodotoxin analogue, in the brachycephalidae frog Brachycephalusephippium. Toxicon.,42: 563-566.

14- Yotsu-Yamashita, M.; Mebs, D.; Kwet, A.and Schneider, M. (2007): Tetrodotoxin and its analog 6-epitetrodotoxin in newts (Triturus spp.; Urodela, Salamandridae) from southern Germany. Toxicon 50: 306-309.

15-Mebs, D. and Yotsu-Yamashita, M. (2012): Tetrodotoxin in North-American newts. Toxicon, 60: 1-120. 
16-Noguchi, T. and Mahmud, Y. (2001): Current methodologies for detection of tetrodotoxin. J. of Toxicology. Toxin Reviews, 20 (1): 35-50.

17-Saoudi, M.; Abdelmouleh, A. and El Feki, A. (2010): Tetrodotoxin: A potent marine toxin. Toxin Rev., (29): 60-70.35.

18- Tosteson, M.T. (1992): Effects of toxins on the voltage- gated Na+ channel, In: Proceedings of the Third International Conference on Ciguatera Fish Poisoning, Puerto Rico. Polyscience Publications, Quebec, p: 47-54.

19- Alonso, D.; Khalil, Z.; Satkunanthan, N. and Livett, B.G. (2003): Drugs from the sea: conotoxins as drug leads for neuropathic pain and other neurological conditions. Mini reviews in medicinal chemistry, 3 (7): 785-787.

20- Ramakrishna, Y.; Manohor, A.I.; Mamata, P. and Shreekant, K.G. (1984): Plants and novel anti-tumour agents: A review Indian Drugs,21:173-185.

21-Ramnath, V.; Kuttan, G. and Kuttan, R. (2002): Anti-tumor effect of abrin on transplanted tumors in mice. J. of Indian Physiol. Pharmacol., 46: 69-77.

22- Ramaswamy, S., Ross, K. N., Lander, E. S. and Golub,T.R.(2002): A molecular signature of metastasis in primary solid tumors., J Nature Genetics. 33 (1): 49-54.

23- Abdin, A. A.; Soliman, N.A. and Saied, E.M.(2014): Effect of propranolol on IL-10, visfatin, Hsp70, iNOS, TLR2, and survivin in amelioration of tumor progression and survival in Solid Ehrlich Carcinoma-bearing mice. Science Direct.,66: 1114-1121.

24- Khedr, N. F. and Khalil, R. M. (2015): Effect of hesperidin on mice bearing Ehrlich solid carcinoma maintained on doxorubicin. J. Inter. Soc. Oncology and BioMarkers., PP:9.

25- Kuttan, G.; Vasudevan, D. and Kuttan, R. (1990): Effect of a preparation from Viscum album on tumor development in vitro and in mice. J. Ethnopharm.,29: 35-41.

26- Sheeja, K.R.; Kuttan, G. and Kuttan, R. (1997): Cytotoxic and antitumor activity of Berberin. Amala. Res. Bull., 17: 73- 76.

27-Gupta, M.; Mazumder, U.K.; Kumar, R.S. and Kumar, T.S. (2004): Antitumor activity and antioxidant role of Bauhinia racemosa against Ehrlich ascites carcinoma in Swiss albino mice. J. Acta Pharmacological Sinica, 25: 1070-1076.

28- Maity, S. ; Mishra, A. and Upadhyay, V. (1999): Effect of wheat bran supplementation on the utilization of mixed straws in goats. Ind. J. Anim. Nutr., 16 (1): 86-88.

29- Wu, Z.; Xie, L.; Xia, G.; Zhang, J.; Nie, Y.; Huc, J.; Wang, S. andZhanga, R. (2005): A new tetrodotoxin-producing actinomycete, Nocardiopsisdassonvillei, isolated from the ovaries of puffer fish Fugurubripes. J. Toxicon, 45: 851-859.

30-LoGrasso, Philip. \& McKelvy, Jeffrey.(2003): Advances in pain therapeutics. J. Chem. Biol., 7:452-456.

31- Fouda, F.M. (2005): Anti-tumor activity of tetrodotoxin extracted from the masked puffer fish, Arothrondia dematus. Egypt. J. Biol.,7: (1-13).

32- Kawabata, T. (1978): Food hygiene examination manual. Tokyo: Japan Food Hygiene Association, 223-241.

33-Noguchi, T. and Mahmud, Y. (2001): Current methodologies for detection of tetrodotoxin. J. of Toxicology. Toxin Reviews, 20 (1): 35-50.

34-Schumann, G. and Klauke, R. (2003): New IFCC reference procedures for the determination of catalytic activity concentrations of five enzymes in serum: preliminary upper reference limits obtained in hospitalized subjects. J. Clinica Chimicaacta., 327(1): 6979.

35- Young, D.S. (2001): Effects of Disease on Clinical Lab. Tests, $4^{\text {th }}$ ed. AACC.

36-Roselli, F.; Livrea1, P. andJirillo, E. (2006): Voltage-gated sodium channel blockers as immune-modulators. Recent Patents on CNS Drug Discover, 1: 83-91. 
37- Abd El-Motelp, B. and Zaazaa, A. (2013): Potential antitumor effect of tetrodotoxin and/or quercetin against Ehrlich carcinoma in mice. J. World pharmacy and pharmaceutical sciences, 2 (6): 6653-6667.

38- Abd El-Dayem, S.M.A.; Fouda, F.M.; Ali, E.H. and El Motelp, B.A.A. (2013): The antitumor effects of tetrodotoxin and/or doxorubicin on Ehrlich ascites carcinoma-bearing female mice. J. of Toxicology and industrial health, 29 (5): 404-417.

39- Mukhtar, H. and Ahmad N (2000): Tea polyphenols: prevention of cancer and optimizing health. Am. J. Clin. Nutr.,71(1): 1698s-1702s.

40-Rajkapoor, B.; Jayakar, B. and Murugesh, N. (2004): Anti-tumor activity of Indigoferaaspalathoides on Ehrlich ascites carcinoma in mice. Ind. J. Pharma., 36 (1): 38-40.

41- Musa, D., Dilsiz, N., Gumushan, H., Ulakoglu, G. and Bitiren, M. (2004): Anti-tumor activity of an ethanol extract of Nigella sativa seeds. J. Biologia, Bratislava 59(6): 735-740.

42- Abd El-Aziz, A.F.; Hefni, M.E. and Shalaby, A. M. (2014): Inhibitory effects of rosemary (RosmarinusofficinalisL.) on Ehrlich ascites carcinoma in mice. International Journal of current research and academic review, 2 (9):330-357.

43- Mahmoud, E.A. (2015): Anti-carcinogenic effect of grape seeds extract against Ehrlich ascites tumor in mice. J. of global Veterinaria, 15 (2): 207-214.

44-Subramanian, V. and Gowry, S. (2011): Antitumor activity and antioxidant role of Brassica oleraceaitalica against Ehrlich ascites carcinoma in Swiss albino mice. Research J. of Pharmaceutical, Biological and Chemical Sciences, 2 (3):275-285.

45- Jayaram, H.N.; Yalowitz, J.A.; Arguello, F. and Greene, J.F. (2002): Toxicity and efficacy of Benzamide Riboside in Cancer Chemotherapy Models. J. of Current Medicinal Chemistry, 9: 787-792.

46- Salem, F.S.; Badr, M.O.T. and Neamat-allah, A.N.F. (2011): Biomedical and pathological studies on the effects of Levamisole and chlorambucil on Ehrich ascites carcinoma-bearing mice. J. of Veterinary Italiana, 47 (1): 89-95.

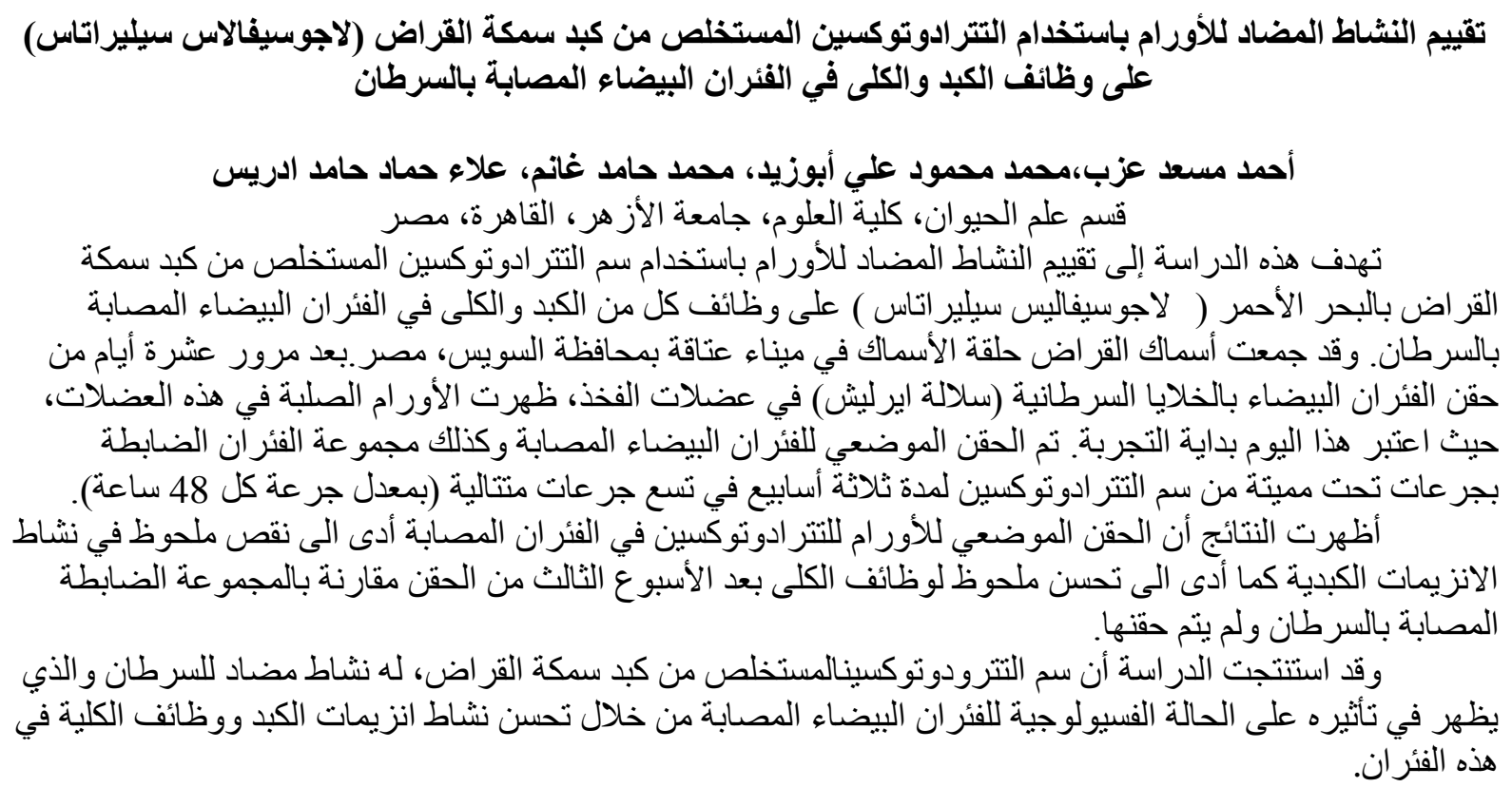

